\title{
CHILDREN'S ANXIETY AND PARENTING STYLES IN FAMILY IN EIGHT-YEAR-OLDS
}

\author{
Ivana Poledňová \\ Masaryk University, Brno, Czech Republic \\ E-mail: polednov@fss.muni.cz
}

\begin{abstract}
Anxiety is a recurrent topic in personality psychology of today. According to Z. Matějček's (1991) estimation, the issue of anxiety assumes the third place as for the number of clients in children's counselling service (behind the issue of intellectual capabilities and ADHD) in the Czech Republic. In children where it occurs to a higher degree, it can have a negative impact on their socialisation, achievements, development of self-confidence. The most influential factor in developing an anxious personality appears to be family environment. If the family fails to satisfy the child's basic needs - feeling of security and confidence - the child's development can be in jeopardy. The current research is concentrated on how the style of parenting in families (the so-called parenting styles) is related to anxiety in children at a younger school age. The aim of the research is to find out what relationship there is between the individual components of parenting in families (positive-negative component, component of requirements - freedom) and anxiety in eight-year-olds. These relationships were inquired into from mothers'perspective by means of questionnaire surveys (Children's Manifest Anxiety Scale and Questionnaire for acquiring the parenting style in family). The data from 407 mothers of eight-year-old children have been analysed. An assumption that anxiety in children of younger school age is significantly influenced by parenting styles in family has been confirmed. The most anxious children appear to be children raised in families with a negative parental emotional involvement towards the child and at the same time with discordant control. They were also some differences in the importance of individual components of parenting by fathers and mothers for anxious orientation of the child identified.
\end{abstract}

Key words: anxiety, anxious children, parenting styles.

\section{Introduction}

Anxiety is a recurrent topic in child's personality psychology of today. In children where it occurs to a higher degree, it can have a negative impact on their socialisation, achievements, development of self-confidence. According to Z. Matějček's (1991) estimation, the issue of anxiety assumes the third place as for the number of clients in children's counselling service (behind the issue of intellectual capabilities and ADHD). The most influential factor in developing an anxious personality appears to be family environment. If the family fails to satisfy the child's basic needs - feeling of security and confidence - the child's development can be in jeopardy. In our paper, we concentrate on how the style of parenting in family (the so-called parenting styles) is related to anxiety in children at a younger school age. 
Anxiety regards inner conditions of the feeling of security that are hard to objectivise; therefore, it is characteristic of fears of one's helplessness and loss of integrity of one's own personality. Anxiety is sometimes referred to as "fear of nothing", it has various intensity and endurance. According to Reykowski (1978), the state of unrest and even anxiety is aroused by influences distorting the image of the world and self. A high level of anxiety contributes to the development of special defence mechanisms whose task is to increase self-control and thus provide personality's integrity. Grzegolowska-Klarkowska (1986), Senejko (2010) claim that anxiety is a factor responsible for triggering of defence mechanisms. Yet also anxiety has some causes and thus it can be viewed also as a condition favourable for triggering of defence mechanisms after the occurrence of an immediate triggering cause. The idea that anxiety is the main and immediate cause of defence established already in times of Sigmund Freud. Freud (1936) regarded anxiety as a result of repressed bodily impulses. He believed that it is a libidinous notion that had been found to be dangerous and hence repressed and without a possibility of expression transformed into anxiety. According to him, anxiety basically means an evident yet transient affective state characterized by tension or fears connected with an increased activity of the autonomous nervous system. Later on, Freud extended the concept of anxiety to a signal of danger. He differentiated objective anxiety - fear, and neurotic anxiety, which either came from the outside world or from the inside world in the form of repressed impulses.

Anxiety is not a simple emotion. One of the best-developed theories derived from the dual concept of anxiety is Spielberger's approach. Spielberger (1972) distinguishes between anxiety as a state and anxiety as a trait. He conceptually defines state anxiety as a transient emotional state of organism aroused by stressful stimuli with clearly perceived unpleasant feelings of tension and worries as well as increased activity of the vegetative nervous system. Trait anxiety is characterised by a relatively steady, individually differentiated tendency to anxiety that is manifested by a different increase of the anxious state. Anxiety as a trait and anxiety as a state are somehow interrelated. The stronger trait anxiety an individual shows, the wider the circle of situations that can be experienced as threatening and can evoke the state of anxiety (Heckhausen, 1980). This relationship is true mainly for situations threatening self-evaluation. Some authors (Endler, Parker, Bagby, Cox, 1991) stem from the presumption that anxiety as a trait (anxiousness) is not one-dimensional but is derived from interplay of more factors. Via factor analysis of S-R anxiety inventory, its authors (Endler, Hunt, Rosenstein, 1962) obtained 3 types of situational factors of anxiousness: interpersonal factor, physical danger and a factor of ambiguity or oddity. By factor analysis of Taylor manifest anxiety scales, O'Connor, Loor and Stafford (qtd. in Czako, Seemanová, Bratská, 1982) obtained 4 factors which they interpret as: a) chronic fear (related to anxiousness, sensitivity and lack of personal confidence), b) consequent instability of the neurovegetative system in situations arousing threat or fear, c) sleeping disorders related to a strong inner tension and d) feeling of personal inferiority.

At younger school-age it is a gradual increase in a child's activity - yet being misunderstood by others who try to slow down the unwanted activity can lead to serious behaviour disorders. During this period, the main source of the child's feeling of security is social support, out of which the most important is parental support. An inappropriate family environment acts as a major factor in creating anxious personality in childhood. Anxiousness is caused both by parenting that is too careful and by strict parenting that fails to respect the individual's potential. A key source of anxiety is also emotionally immature parents who are inconsistent in parenting. Apart from that, refusing the child by either or both parents leads to manifestations of anxiety as well. A similar effect making the child confused has a discordant family environment or discordancy in parenting (Vymětal, 1979, Čáp, Boschek, 1994).

\section{Research Focus}

The aim of the research is to find out what relationship there is between the individual components of parenting in families (positive - negative component, component of requirements - freedom) and anxiety in eight-year-olds. These relationships were inquired into from a mother's perspective by means of questionnaire surveys. Moreover, we also examined differences in anxiety between boys and girls. 
Methodology of Research

\section{Sample of Research}

The presented research is part of the international project ELSPAC (The European Longitudinal Study of Pregnancy and Childhood). Data collection started with seven-year-olds only via questionnaires - questionnaires developed by an international team of researchers were sent to the families by post. At 8 years of age, an examination began when the examined child was physically present for the first time (usually together with the mother) - this part of the research had a somatic and psychological part. The results presented in this paper are from the psychological part of this research, which was carried out at the Institute for Research on Children, Youth and Family at the Faculty of Social Studies, Masaryk University in Brno. Respondents in the Czech part of the research were from the city of Brno and its surroundings.

In this study, we process data from 407 mothers of eight-year-olds - these mothers came personally with their children to the psychological examination at the university. Mother's answers pertaining to their children were analysed.

\section{Instrument and Procedures}

The following questionnaire methods were used for the research:

1. Children's Manifest Anxiety Scale - CMAS (Castaneda, McCandless, Palermo, 1956) modified by J. Fischer and Š. Gjuričová (1974). It is a self-assessment method, one-dimensional questionnaire in which the person under examination is asked about anxiety symptoms.

The scale is composed of 61 items, out of which 48 concern anxiety symptoms and 13 items make up the so-called Lie Scale. The scale has a high reliability and validity and reliable normative data. It is aimed at the population of children attending standard classes 4-6. In our research, the method was applied to the population of younger (8-year-old) children and thus we changed its instruction - children's mothers completed the questionnaire in the way they thought their children would complete it.

2. Questionnaire for acquiring the parenting style in family (Čáp, Boschek, 1994) is derived from the model of four components of parenting and their combinations. Two of these components, i.e. components of the requirements and freedom, characterize parental control. The emotional involvement to the child is composed of a positive and negative component. It is possible to work with individual components of parenting separately; however, a more synthetic picture of family parenting implies their combination. An empirically verified form of the model assumes nine combinations or possible styles of parenting in family (see tab. 1). The questionnaire has a satisfactory reliability and validity. The correlation coefficient for the test - retest reliability is in the range from 0.74 to 0.87 , the internal consistency (Cronbach's $\alpha$ ) ranges from 0.59 to 0.82 .

Table 1. Model of nine fields of parenting style.

\begin{tabular}{|c|c|c|c|c|}
\hline \multirow{2}{*}{$\begin{array}{l}\text { Emotional } \\
\text { involvement }\end{array}$} & \multicolumn{4}{|c|}{ Control } \\
\hline & Strong & Medium & Weak & Discordant \\
\hline Negative & \multicolumn{2}{|c|}{$\begin{array}{l}\text { 1: autocratic, traditional, patriarchal } \\
\text { parenting }\end{array}$} & $\begin{array}{l}\text { 2: liberal parenting with a } \\
\text { lack of interest in the child }\end{array}$ & $\begin{array}{l}\text { 3: personal form of } \\
\text { parenting, discordant control } \\
\text { with a negative relationship }\end{array}$ \\
\hline $\begin{array}{l}\text { Negatively } \\
\text { positive }\end{array}$ & \multicolumn{4}{|c|}{$\begin{array}{l}\text { 9: emotionally discordant parenting; one of the parents is rejecting, the other one is extremely } \\
\text { positive or the child is in coalition with him/her }\end{array}$} \\
\hline Positive & \multirow{2}{*}{$\begin{array}{l}\text { 4: strict and at } \\
\text { the same time } \\
\text { kind parenting }\end{array}$} & \multirow{2}{*}{$\begin{array}{l}\text { 5: best form of } \\
\text { parenting possible } \\
\text { with mutual } \\
\text { understanding and } \\
\text { reasonable control }\end{array}$} & $\begin{array}{l}\text { 6: kind parenting without } \\
\text { requirements and limits }\end{array}$ & \multirow{2}{*}{$\begin{array}{l}7 \text { : discordant control } \\
\text { relatively balanced } \\
\text { by positive emotional } \\
\text { involvement }\end{array}$} \\
\hline Extremely positive & & & $\begin{array}{l}\text { 8: friendly relationship, } \\
\text { voluntary abiding of norms }\end{array}$ & \\
\hline
\end{tabular}


The questionnaire enables us to acquire paternal and maternal style of parenting separately and

the style of family parenting as a whole.

Parenting control of an individual parent is evaluated accordingly:

If the parent has a high component of requirements and at the same time

- has a high component of freedom, it is discordant control

- has a lower component of freedom, it is strong control.

If the parent has a lower component of requirements and at the same time has

- a low component of freedom, it is strong control

- a moderately high component of freedom, it is medium control

- a high component of freedom, it is weak control.

The parenting control of family as a whole is weak if both parents show weak control. Similarly, strong and medium control is always determined according to the agreement of control of both parents. If either of the parents has medium control, the control of the family as a whole is regarded as discordant. Moreover, the control of the family is discordant also in case of the combination of weak control of one parent and strong control of the other.

The emotional involvement of the family as a whole is evaluated on the grounds of the quality of the involvement of both parents. The involvement of the family as a whole to the child is:

negative - when one or both of the parents have a negative emotional involvement while neither of them has an extremely positive emotional involvement.

positive - both parents have a positive emotional involvement, or one of them has a positive and the other one medium emotional involvement.

extremely positive - one of the parents has a zero and the other one only a minimal value of the negative component and at the same time, they have a high positive component.

negatively positive- one of the parents has a negative and the other one extremely positive emotional involvement to the child.

If one of the parents has a medium emotional involvement, the emotional involvement in family is assessed according to the emotional involvement of the other parent as positive or negative.

In the research, the original recording sheet was used; however, its instructions were modified - it was completed by mothers as they imagined how their children would fill them in. 385 mothers completed the questionnaire also for their spouses.

\section{Data Analysis}

Mothers completed both questionnaires (among other methods) during a complex psychological examination of their children. The questionnaires were evaluated and processed by conventional statistical procedures for the whole sample.

\section{Results of Research}

\section{Analysis of the Basic Components of Parenting for Mothers and Fathers}

In table 2 , there are mean values in the individual components of parenting separately for fathers and mothers. In parenting, it is the positive component that is the most frequent in fathers and mothers, i.e. parents show a strong positive emotional involvement with their children. An approximately the same occurrence, much lower than in the positive component, is further held by components of the requirements and freedom, the lowest occurrence was found in the negative component, i.e. a negative emotional involvement.

When comparing differences between the individual components of parenting on the part of their mothers and fathers, we discovered that there is statistically much higher value of the individual components of parenting in mothers than with fathers (see table 3 ). 
Table 2. Mean values and standard deviations for the individual components of parenting.

\begin{tabular}{ccccccccc}
\hline & \multicolumn{2}{c}{$\begin{array}{c}\text { Positive } \\
\text { component }\end{array}$} & \multicolumn{2}{c}{$\begin{array}{c}\text { Negative } \\
\text { component }\end{array}$} & $\begin{array}{c}\text { Component } \\
\text { of requirements }\end{array}$ & $\begin{array}{c}\text { Component } \\
\text { of freedom }\end{array}$ \\
\cline { 2 - 8 } & Father & Mother & Father & Mother & Father & Mother & Father & Mother \\
\hline $\begin{array}{c}\mathrm{N} \\
\begin{array}{c}\text { Number of respondents) } \\
\mathrm{m}\end{array}\end{array}$ & 385 & 407 & 385 & 407 & 385 & 407 & 385 & 407 \\
$\begin{array}{c}\text { (mean value) } \\
\text { SD }\end{array}$ & 27.54 & 28.4 & 11.45 & 11.67 & 15.49 & 16.22 & 16.37 & 16.72 \\
(standard deviation) & 2.43 & 1.51 & 1.93 & 1.83 & 2.84 & 2.48 & 2.98 & 2.68 \\
\hline
\end{tabular}

Table 3. Two-sample t-tests for differences in the individual components of parenting in fathers and mothers.

\begin{tabular}{ccccc}
\hline & $\begin{array}{c}\text { Difference of averages } \\
\text { (fathers- mothers) }\end{array}$ & SD & $\mathrm{t}$ & $\mathrm{p}$ \\
\hline Positive component & -0.84 & 2.04 & -8.09 & 0.000 \\
$\begin{array}{c}\text { Negative component } \\
\text { Component } \\
\text { of requirements }\end{array}$ & -0.24 & 1.73 & -2.75 & 0.006 \\
Component of freedom & -0.75 & 2.48 & -5.91 & 0.000 \\
\hline
\end{tabular}

\section{Relationship between Children's Anxiety and the Basic Components of Parenting}

In table 4, there are correlation coefficients between the scores of anxiety and parenting components separately for mothers and fathers. We discovered that in maternal parenting, there is a statistically evident negative relationship between the child's anxiety and the negative component of parenting, component of requirements and component of freedom. In paternal parenting, we obtained the same result, only the component of freedom does not show a statistically evident correlation with anxiety. Therefore, free parenting by father appears not to affect the formation of the child's anxious personality to such a degree as it is in mothers. The values of coefficients imply that the most significant influence on child's anxiety has a negative emotional involvement of both parents towards the child.

Table 4. Correlation coefficients (Kendall's coefficient Tau-b) between the scores of anxiety and components of parenting separately for mothers and fathers.

\begin{tabular}{ccccccccc}
\hline & Positive component & Negative component & $\begin{array}{c}\text { Component } \\
\text { of requirements }\end{array}$ & $\begin{array}{c}\text { Component } \\
\text { of freedom }\end{array}$ \\
\cline { 2 - 8 } & Father & Mother & Father & Mother & Father & Mother & Father & Mother \\
\hline $\begin{array}{c}\text { Anxiety } \\
\begin{array}{c}p \\
\text { (value of } \\
\text { significance) }\end{array}\end{array}$ & -0.14 & -0.11 & 0.24 & 0.24 & 0.14 & 0.19 & 0.06 & 0.12 \\
$\begin{array}{c}\mathrm{N} \\
\text { (number of } \\
\text { respondents) }\end{array}$ & 0.000 & 0.003 & 0.000 & 0.000 & 0.000 & 0.000 & 0.112 & 0.001 \\
\hline
\end{tabular}


In table 5, there are mean values of anxiety in boys and girls depending on the style of parenting defined by the so-called parenting field according to the questionnaire of the Czech author J. Čáp.

\section{Table 5. Mean values of anxiety in boys and girls depending on the style of parenting.}

\begin{tabular}{ccccc}
\hline & \multicolumn{4}{c}{ Child's sex } \\
\cline { 2 - 5 } $\begin{array}{c}\text { Parenting style } \\
\text { (parenting field) }\end{array}$ & \multicolumn{3}{c}{ Male } & \multicolumn{2}{c}{ Female } \\
\cline { 2 - 5 } & $\begin{array}{c}\mathrm{m} \\
\text { (mean value) }\end{array}$ & $\begin{array}{c}\mathrm{N} \\
\text { (number } \\
\text { of respondents) }\end{array}$ & $\begin{array}{c}\mathrm{m} \\
\text { (mean value) }\end{array}$ & $\begin{array}{c}\mathrm{N} \\
\text { (number } \\
\text { of respondents) }\end{array}$ \\
\hline 1 & 16.82 & 17 & 21.27 & 11 \\
2 & 15.75 & 4 & 22.43 & 7 \\
3 & 20.71 & 14 & 25.11 & 18 \\
4 & 13.26 & 43 & 12.22 & 32 \\
5 & 14.91 & 43 & 14.00 & 35 \\
6 & 14.67 & 15 & 14.45 & 11 \\
7 & 16.74 & 23 & 19.41 & 17 \\
8 & 17.54 & 24 & 12.59 & 29 \\
9 & 16.67 & 3 & 12.67 & 3 \\
\hline
\end{tabular}

A detailed statistical verification of the cogency of differences between the individual parenting styles (boys and girls together) showed that the most anxious children appear to be children raised in families with parents' negative emotional involvement towards the child and at the same time with discordant control (parenting field 3). The least anxious were children with an extremely positive emotional involvement of parents towards the child and at the same time strong control (parenting field 4).

\section{Discussion}

In today's psychology, issues of anxiety are being widely researched. Anxiety can have a crucial impact on performance motivation and an overall human performance (see e.g. Stuchlíková, Klinger, 1996), but also the overall level of optimism (Dewberry, Richardson, 1990). Aspects of social anxiety are an important predictor of the feeling of loneliness among peers.

The relationship between parenting environment in the family and occurrence of anxiety in children has been repeatedly confirmed by researchers. J. Čáp (Čáp, Boschek, 1994) in his research verified the relationship between stability - lability in Eysenck's view and parenting styles in family; the pole of lability included anxiety symptoms. It turned out that lability examined by Eysenck's questionnaire is related to the negative emotional involvement, especially when the high negative component occurs in the parent of the opposite sex. Lability was also related to discordant and strong control. In other research studies by J. Cáp conducted in relation to the individual parenting fields, the highest number of labile children was acquired in field 3 (negative emotional involvement with discordant control), followed by field 1 (negative emotional involvement with strong control) and field 2 (negative emotional involvement with weak control). The most stabile ones occurred in field 5 (positive emotional involvement with medium control) and field 8 (weak control with an extremely positive emotional involvement).

This research, too, has confirmed that in relation to anxiety, the combination of discordant control and negative emotional involvement is the least favourable. Regarding the fact that the questionnaire was completed by children's mothers, we examined their subjective view of their parenting, which 
OF PSYCHOLOGY

IN THE $21^{\text {st }}$ CENTURY Volume 7, 2013

can be affected by a series of modifying factors and can differ from the children's perspective. In a study by Siqueland et al. (1996), it was discovered that anxious children's parents can be evaluated differently by these children and by independent observers. Independent observers assessed parents of anxious children as not providing enough psychological autonomy while children aged 9-12 themselves viewed their parents as not very accepting.

It is evident that the influence of family and family upbringing in childhood is crucial. However, it is necessary to become aware of the fact that an important role in anxiety experiencing and manifestations is played by other significant personality traits and wider social and motivational variables. Even in an adverse style of parenting, personality's positive development is achievable or, in other words, it is possible to try to accomplish it. It is just as important that parenting does not work only in one direction but it is a mutual interaction between parents and their child.

\section{Conclusions}

The assumption about the relation between anxiety in children of younger school age and parenting styles in family has been confirmed. It has become clear that in the parenting of eight-year-olds, it is the positive component that is the most frequent in parenting, i.e. parents show a strong positive emotional involvement to their children, more so on the part of mothers than fathers.

Children's anxiety is closely related to the individual components of parenting. From research it is evident that emotional relationship with the child can be considered as a key moment in optimal upbringing. In maternal parenting, child's anxiety is lower in family with a positive emotional involvement towards the child and higher in family with demanding requirements imposed on the child, a high degree of freedom and a negative emotional involvement. In fathers, we obtained the same result, only the component of freedom does not show a statistically evident correlation with anxiety. Therefore, free parenting by father appears not to be in relation with anxious personality of their children affect the formation of the child's anxious personality to such a degree as it is in mothers.

It was also found that the most anxious children appear to be children raised in families with a negative parental emotional involvement towards the child and at the same time with discordant control. On the contrary, the least anxious are children with an extremely positive parental involvement towards the child and at the same time with strong control. These findings would be appropriate applied in counseling practice.

\section{References}

Castaneda, A., McCandless, B. R., Palermo, D. S. (1956). The children's form of the manifest anxiety scale. Child Development, 27 (3), 317-326.

Czako, M., Seemanová, M., Bratská, M. (1982). Emócie. Bratislava: SPN.

Čáp, J., Boschek, P. (1994). Dotaznik pro zjištování způsobu výchovy v rodině. Bratislava: Psychodiagnostika.

Dewberry, C., Richardson, S. (1990). Effect of anxiety on optimism. Journal of Social Psychology, 130, $731-738$

Endler, N. S., Hunt, J. McV., Rosenstein, A. J. (1962). An S-R Inventory of Anxiousness. Psychological Monographs, 76 (17), 1-33.

Endler, N. S., Parker, J. D., Bagby, R. M., Cox, B. J. (1991). Multidimensionality of State and Trait Anxiety:

Factor Structure of the Endler Multidimensional Anxiety Scales. Journal of Personality and Social Psychology, 60 (6), 919-926.

Fischer, J., Gjuričová, Š. (1974). Škála zjevné úzkosti pro děti - CMAS. Bratislava: Psychodiagnostické a didaktické testy.

Freud, S. (1936). The problem of anxiety. New York: Norton.

Grzegolowska - Klarkowska, H. J. (1986). Mechanizmy obronne osobowości. Warszawa: PWN.

Heckhausen, H. (1980). Motivation und Handeln. Berlin: Springer. 
Matějček, Z. (1991). Praxe dětského psychologického poradenství. Praha: SPN.

Reykowski, J. (1978). Osobowość. In: T. Tomaszewski (Ed.). Psychologia. Warszawa: PWN.

Senejko, A. (2010). Obrona psychologiczna jako narzędzie rozwoju. Na przykładzie adolescencji. Warszawa: PWN.

Siqueland, L., Kendall, P. C., Steinberg, L. (1996). Anxiety in children: Perceived family environments and observed family interaction. Journal of Clinical Child Psychology, 25 (2), 225-237.

Spielberger, Ch. D. (Ed.). (1972). Anxiety. Current Trend in Theory and Research. New York: Academic Press.

Stuchlíková, I., Klinger, E. (1996). Úzkost a motivační struktura osobnosti. In Retrospektíva. Realita a perspektíva psychológie na Slovensku. Bratislava: Stimul, 97-99.

Vymětal, J. (1979). Úzkostné děti a jejich výchova. Praha: SPN.

Advised by Jiři Dan, Masaryk University,

Brno, Czech Republic

Received: September 30, 2013

Accepted: November 21, 2013

Ivana Poledňová PhD., Researcher, Masaryk University, Faculty of Social Sciences, Department of Psychology,

Joštova 10, 60200 Brno, Czech Republic.

E-mail: polednov@fss.muni.cz

Website: http://www.muni.cz 